\title{
Spontaneous pneumomediastinum in COVID-19 patients.
}

\section{Case series}

\author{
Francina V. Bolaños-Morales, ${ }^{1} \mathrm{~J}$. Alfredo Santibáñez-Salgado, ${ }^{*}$ Cristóbal Guadarrama-Pérez, ${ }^{2}$ \\ Julio de J. Herrera-Zamora, ${ }^{1}$ Francisco J. Armas-Zárate ${ }^{1}$ and Patricio J. Santillán-Doherty ${ }^{1}$ \\ ${ }^{1}$ Cardiothoracic Surgery Department; ${ }^{2}$ Emergency Department. Instituto Nacional de Enfermedades Respiratorias, Mexico City, Mexico
}

\begin{abstract}
Spontaneous pneumomediastinum is defined as the presence of free air within the mediastinum without an apparent cause such as chest trauma. It is a benign, self-limiting condition that is conservatively treated. Clinical diagnosis is based on two symptoms: chest pain and dyspnea; and on a particular sign: subcutaneous emphysema. It has been reported in patients with influenza $A$ (H1N1) and severe acute respiratory syndrome; however, it has been rarely observed in COVID-19 patients. In this work, we describe six male patients with COVID-19, aged between 27 and 82 years, who presented with spontaneous pneumomediastinum and subcutaneous emphysema; both conditions were completely resorbed with conservative management.
\end{abstract}

KEY WORDS: Spontaneous pneumomediastinum. Subcutaneous emphysema. Macklin effect. COVID-19.

\section{Neumomediastino espontáneo en pacientes COVID-19. Serie de casos}

\section{Resumen}

El neumomediastino espontáneo es la presencia de aire libre en el mediastino sin el antecedente de alguna causa como trauma de tórax. Es una condición benigna autolimitada que se trata en forma conservadora. El diagnóstico clínico se basa en dos síntomas: dolor torácico y disnea; y en un signo en particular: enfisema subcutáneo. Ha sido reportado en pacientes con influenza A (H1N1) y síndrome respiratorio agudo grave; sin embargo, ha sido raramente observado en pacientes con COVID-19. En este trabajo describimos seis pacientes del sexo masculino con COVID-19, con edades entre 27 y 82 años, que presentaron neumomediastino espontáneo y enfisema subcutáneo; ambos se reabsorbieron totalmente con manejo conservador.

PALABRAS CLAVE: Neumomediastino espontáneo. Enfisema subcutáneo. Efecto Macklin. COVID-19.

\section{Introduction}

Spontaneous pneumomediastinum (PNM) is presence of free air within the mediastinum not preceded by any cause such as chest trauma or medical or surgical procedure, which causes symptoms such as retrosternal pain, dyspnea, hoarseness and odynophagia. It is usually a benign and self-limiting condition, which often goes unnoticed by doctors. It has an incidence that ranges from one in 8,005 to one in 42,000 emergency admissions. It may not be identified on physical examination; however, its presence is
Correspondence:

*J. Alfredo Santibáñez-Salgado

E-mail: alf36@ hotmail.com
Gac Med Mex. 2021;157:110-114

Contents available at PubMed

www.gacetamedicademexico.com

0016-3813/@ 2020 Academia Nacional de Medicina de México, A.C.. Published by Permanyer. This is an open access article under the CC BY-NC-ND license (http://creativecommons.org/licenses/by-nc-nd/4.0/). 


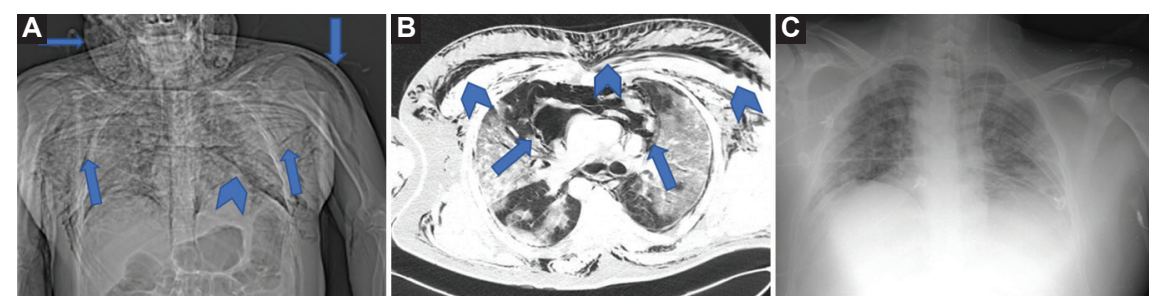

Figure 1. A: Topogram of the computed axial tomography scan performed at admission, showing subcutaneous emphysema on the face, neck, chest and arms (arrows). B: Computed axial tomography at admission, showing pneumomediastinum and subcutaneous emphysema (arrowhead), with bilateral lung consolidation and bilateral ground glass areas. C: Chest X-ray obtained on the seventh day of hospitalization; no evidence of pneumomediastinum or subcutaneous emphysema is observed.

suspected in patients with subcutaneous emphysema without a history of chest trauma., ${ }^{1,2}$

In this research, we report six male patients with COVID-19, who presented with spontaneous PNM and subcutaneous emphysema, which was fully reabsorbed with conservative management.

\section{Methods}

Patients with a confirmed COVID-19 diagnosis, who presented with PNM and subcutaneous emphysema, were included. The patient or a legally authorized person granted informed consent.

\section{Results}

From February 28 to September 30, 2020, 1,300 patients were admitted to the National Institute of Respiratory Diseases, in Mexico City, with a diagnosis of COVID-19, confirmed by pharyngeal or nasal exudate PCR. Six male patients aged between 27 and 82 years presented with spontaneous PNM and subcutaneous emphysema. Four patients had spontaneous PNM and subcutaneous emphysema prior to arrival at the emergency department and two, 24 hours after having been intubated for ventilatory mechanical support. One patient arrived at the Emergency Department with subcutaneous emphysema in the head, neck, chest and both arms, as well as disseminated PNM (Fig. 1); he was intubated upon admission due to the severity of respiratory failure. Five patients had subcutaneous emphysema and mild PNM. In the computed axial tomography images of all patients, ground glass images and areas of consolidation were observed in both lung fields (Figs. 1, 2 and 3).

All patients had malaise, chest pain, odynophagia, and coughing spells; five, severe dyspnea and low

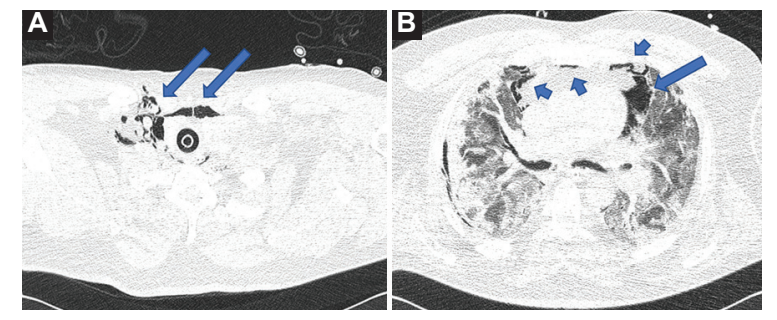

Figure 2. A: Computed axial tomography scan performed at admission; pneumomediastinum and subcutaneous emphysema are observed (arrows). B: Computed axial tomography scan performed at admission; areas of bilateral lung consolidation and areas of bilateral ground glass are observed. Pneumomedastinum (arrows).

oxygen saturation despite non-invasive supplemental oxygen. One patient with very mild respiratory symptoms was discharged one week after admission, in good conditions. In all subjects, spontaneous PNM and subcutaneous emphysema were conservatively managed, with total reabsorption of both between days 7 and 12 of hospital stay (Figs. 1 and 3). Three patients were discharged in good health conditions and three died of COVID-19 complications. Demographic characteristics, management, and outcome are summarized in tables 1 and 2 .

\section{Discussion}

Spontaneous pneumomediastinum is the result of a pressure variation between the alveolus and the pulmonary interstitium that leads to alveolar rupture..$^{1,2}$ Two mechanisms can generate this pressure gradient: the first one is an increase in intra-alveolar pressure (intentional Valsalva maneuver), described as a precipitating factor; the second is a pressure decrease in the perialveolar interstitial space, which is observed during intense respiratory effort or a rapid decrease in atmospheric pressure, which have been described as predisposing factors. ${ }^{3,4}$ Once alveolar rupture occurs, 


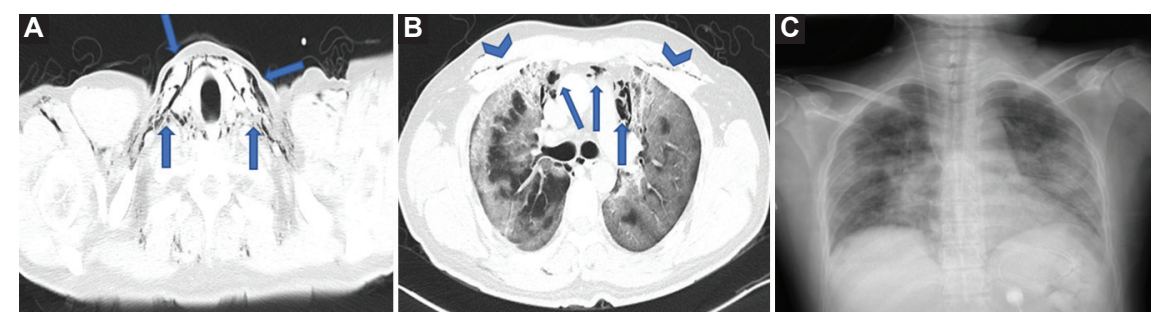

Figure 3. A: Computed axial tomography at admission; pneumomediastinum and cervical region subcutaneous emphysema are observed (arrows). B: Computed axial tomography at admission; areas of bilateral lung consolidation and areas of bilateral ground glass, indicative of pneumomediastinum (arrows), as well as anterior chest region subcutaneous emphysema (arrowhead), are observed. C: Chest $X$-ray carried out on hospitalization day 11; there is no evidence of pneumomediastinum or subcutaneous emphysema.

Table 1. Demographic data and clinical evolution

\begin{tabular}{|c|c|c|c|c|c|c|}
\hline Variable & Patient 1 & Patient 2 & Patient 3 & Patient 4 & Patient 5 & Patient 6 \\
\hline Age (years) & 37 & 47 & 27 & 55 & 38 & 82 \\
\hline Gender & Male & Male & Male & Male & Male & Male \\
\hline Comorbidity & Obesity & Obesity & No & $\mathrm{IHD}$ & No & Obesity \\
\hline $\begin{array}{l}\text { Time with COVID-19 symptoms } \\
\text { prior to hospital admission }\end{array}$ & 20 days & 10 days & 11 days & 11 days & 7 days & 21 days \\
\hline Ventilatory support & IMV & IMV & IMV & IMV & No & IMV \\
\hline PEEP $\left(\mathrm{cm} \mathrm{H}_{2} \mathrm{O}\right)$ & 6 & 8 & 6 & 8 & No & 6 \\
\hline Spontaneous pneumomediastinum & $\begin{array}{l}\text { Yes (prior to } \\
\text { IMV) }\end{array}$ & $\begin{array}{l}\text { Yes (prior to } \\
\text { IMV) }\end{array}$ & $\begin{array}{l}\text { Yes (prior to } \\
\text { IMV) }\end{array}$ & $\begin{array}{l}\text { Yes ( } 24 \mathrm{~h} \text { after } \\
\text { IMV) }\end{array}$ & Yes & $\begin{array}{l}\text { Yes } \\
\text { ( } 24 \text { h after IMV) }\end{array}$ \\
\hline Subcutaneous emphysema & $\begin{array}{l}\text { Yes (prior to } \\
\text { IMV) }\end{array}$ & $\begin{array}{l}\text { Yes (prior to } \\
\text { IMV) }\end{array}$ & $\begin{array}{l}\text { Yes (prior to } \\
\text { IMV) }\end{array}$ & $\begin{array}{l}\text { Yes ( } 24 \mathrm{~h} \text { after } \\
\text { IMV) }\end{array}$ & Yes & $\begin{array}{l}\text { Yes ( } 24 \mathrm{~h} \text { after } \\
\text { IMV) }\end{array}$ \\
\hline Pneumothorax & No & No & No & No & No & No \\
\hline Spontaneous PNM treatment & Conservative & Conservative & Conservative & Conservative & Conservative & Conservative \\
\hline Spontaneous PNM resolution & IH day 7 & $\mathrm{IH}$ day 10 & IH day 11 & IH day 10 & IH day 7 & IH day 12 \\
\hline Outcome & $\begin{array}{l}\text { Discharge at } \\
\text { IH day } 27\end{array}$ & $\begin{array}{l}\text { Deceased on } \\
\text { IH day } 14\end{array}$ & $\begin{array}{l}\text { Discharge at } \\
\text { IH day } 25\end{array}$ & $\begin{array}{l}\text { Deceased on } 1 \mathrm{H} \\
\text { day } 22\end{array}$ & $\begin{array}{l}\text { Discharge at } \\
\text { IH day } 7\end{array}$ & $\begin{array}{l}\text { Deceased on } \\
\text { IH day } 27\end{array}$ \\
\hline
\end{tabular}

PEEP = positive end-expiration pressure, IMV = invasive mechanical ventilation, $I \mathrm{H}=$ in-hospital, $I \mathrm{HD}=$ ischemic heart disease, $\mathrm{PNM}=$ pneumomediastinum .

the air is centripetally expelled through the pulmonary interstitium along the bronchoalveolar sheaths towards the pulmonary hilum and the mediastinum, and can continue towards the cervical subcutaneous planes and the pleura. This pathophysiological mechanism is known as the Macklin effect. ${ }^{1-4}$ Presence of at least one precipitating factor such as a coughing spell, emesis and vigorous exercise was observed in 21 to $88.9 \%$ of patients, and at least one predisposing factor such as smoking, asthma, respiratory infection and interstitial lung disease was present in $22 \%$ of patients with spontaneous PNM. ${ }^{3,4}$

The alveolus is prone to rupture in patients with severe viral pneumonia because the virus damages the alveolar membrane given that it infects type I and II pneumocytes. Most patients with viral pneumonia have at least the precipitating factor of cough, which can cause alveolar rupture and PNM development. ${ }^{4-6}$

The described patients had dry cough, chest pain, myalgia, and malaise; four had fever, subcutaneous crackles with no history of chest trauma or manipulation of the airway or esophagus. Two patients developed PNM and subcutaneous emphysema 24 hours after having been intubated for invasive mechanical ventilatory support. We hypothesized that PNM was not related to invasive mechanical ventilation. Alveolar rupture has been reported not to be related to the use of positive end-expiratory pressure 
Table 2. Patient signs, symptoms and arterial blood gas upon arrival at emergency department

\begin{tabular}{|c|c|c|c|c|c|c|}
\hline Parameter & Patient 1 & Patient 2 & Patient 3 & Patient 4 & Patient 5 & Patient 6 \\
\hline Coughing & Severe spells & Severe spells & Mild spells & Mild spells & Mild spells & Severe spells \\
\hline Chest pain & Yes & Yes & Yes & Yes & Yes & Yes \\
\hline Odynophagia & Yes & Yes & Yes & Yes & Yes & Yes \\
\hline Malaise & Yes & Yes & Yes & Yes & Yes & Yes \\
\hline Temperature & $36.5^{\circ} \mathrm{C}$ & $39.6^{\circ} \mathrm{C}$ & $37^{\circ} \mathrm{C}$ & $38^{\circ} \mathrm{C}$ & $37.1^{\circ} \mathrm{C}$ & $38^{\circ} \mathrm{C}$ \\
\hline Dyspnea & Yes & Yes & Yes & Yes & No & Yes \\
\hline Heart rate & $110 x^{\prime}$ & $120 x^{\prime}$ & $106 x^{\prime}$ & $104 x^{\prime}$ & $90 x^{\prime}$ & $100 x^{\prime}$ \\
\hline $\begin{array}{l}\text { Respiratory } \\
\text { rate }\end{array}$ & $34 x^{\prime}$ & $30 x^{\prime}$ & $40 x^{\prime}$ & $30 x^{\prime}$ & $20 x^{\prime}$ & $40 x^{\prime}$ \\
\hline $\mathrm{O}_{2}$ saturation & $\begin{array}{c}43 \% \text { with nasal } \\
\text { prongs at } 15 \mathrm{~L} / \mathrm{min}\end{array}$ & $\begin{array}{c}65 \% \text { with nasal } \\
\text { prongs at } 15 \mathrm{~L} / \mathrm{min}\end{array}$ & $\begin{array}{c}86 \% \text { with nasal } \\
\text { prongs at } 10 \mathrm{~L} / \mathrm{min}\end{array}$ & $\begin{array}{c}56 \% \text { with nasal } \\
\text { prongs at } 15 \mathrm{~L} / \mathrm{min}\end{array}$ & $\begin{array}{c}96 \% \text { while breathing } \\
\text { ambient air }\end{array}$ & $\begin{array}{l}80 \% \text { with nasal } \\
\text { prongs at } 15 \mathrm{~L} / \mathrm{min}\end{array}$ \\
\hline $\mathrm{pH}$ & 7.19 & 7.42 & 7.45 & 7.15 & 7.46 & 7.17 \\
\hline $\mathrm{pO}_{2}, \mathrm{~mm} \mathrm{Hg}$ & 46 & 24 & 58.2 & 65.3 & 93.6 & 82.9 \\
\hline $\mathrm{pCO}_{2}, \mathrm{~mm} \mathrm{Hg}$ & 68.7 & 24 & 30.6 & 69.1 & 30 & 25.8 \\
\hline $\mathrm{HCO}_{2}, \mathrm{mmol} / \mathrm{L}$ & 25 & 16.2 & 21.3 & 18.8 & 27.3 & 9.1 \\
\hline
\end{tabular}

in patients with SARS, but to invasive mechanical ventilatory support with plateau pressures higher than $35 \mathrm{~cm} \mathrm{H}_{2} \mathrm{O}^{5-8}$ In our patients, invasive mechanical ventilatory support did not worsen PNM or subcutaneous emphysema.

Subcutaneous emphysema and a history of severe coughing spells suggested the spontaneous PNM diagnosis, which was confirmed by chest $\mathrm{X}$-ray and computed tomography. Chest X-ray is the gold standard for diagnosing spontaneous PNM; however, half the cases can go unnoticed without lateral chest $\mathrm{X}$-ray, ${ }^{1,2}$ which cannot be practiced in patients with invasive mechanical ventilatory support. Chest computed axial tomography is the most reliable imaging study to confirm spontaneous PNM; however, follow-up is carried out with serial chest X-rays due to the possibility of pneumothorax, which can cause cardiopulmonary compromise and whose treatment will require the placement of a drainage system or surgical treatment if air leak continues. ${ }^{9}$

Spontaneous PNM and subcutaneous emphysema clinical evolution in our patients was good, with gradual reabsorption of air through tissues, despite COVID-19 severity. Spontaneous PNM is usually a self-limiting, benign condition, which is why conservative management is sufficient. ${ }^{9}$

\section{Conclusions}

Patients with COVID-19 have coughing spells, which can cause spontaneous PNM and subcutaneous emphysema. PNM is suspected in patients with cervical or thoracic subcutaneous emphysema without a history of chest trauma. Clinical follow-up, as well as radiological evaluation, are sufficient to detect improvement or cardiorespiratory complications. PNM patients can be conservatively managed, and invasive mechanical ventilation positive pressure does not exacerbate PNM or subcutaneous emphysema.

\section{Conflict of interests}

The authors declare that they have no conflicts of interest.

\section{Funding}

No financial funding was received to carry out this work.

\section{Ethical disclosures}

Protection of human and animal subjects. The authors declare that no experiments were performed on humans or animals for this research. 
Confidentiality of data. The authors declare that they followed the protocols of their work center on the publication of patient data.

Right to privacy and informed consent. The authors obtained informed consent from the patients or subjects referred to in the article.

\section{References}

1. Okada M, Adachi H, Shibuya $Y$, Ishikawa S, Hamabe $Y$. Diagnosis and treatment of patients with spontaneous pneumomediastinum. Resp Investig. 2014;52:36-40.

2. Kim KS, Jeon HW, Moon Y, Kim YD, Ahn MI, Park JK, et al. Clinica experience of spontaneous pneumomediastinum: diagnosis and treatment. J Thorac Dis. 2015;7:1817-1824.
3. Meireles J, Neves S, Castro A, Franca M. Spontaneous pneumomediastinum revisited. Respir Med CME. 2011;4:181-183.

4. Dionísio P, Martins L, Moreira S, Manique A, Macedo R, Caeiro F, Boal L, Bárbara C. Spontaneous pneumomediastinum: experience in 18 patients during the last 12 years. J Bras Pneumol. 2017;43:101-105.

5. Chekkoth SM, Naga SR, Valsala N, Kumar P, Raja RS. Spontaneous pneumomediastinum in $\mathrm{H} 1 \mathrm{~N} 1$ infection: uncommon complication of a common infection. J R Coll Physicians Edinb. 2019;49:298-300.

6. Chu CM, Leung YY, Hui JYH, Hung IFN, Chan VL, Leung WS, et al. Spontaneous pneumomediastinum in patients with severe acute respiratory syndrome. Eur Resp J. 2004;23:802-804.

7. Wang J, Su X, Zhang T, Zheng C. Spontaneous pneumomediastinum: a probable unusual complication of coronavirus disease 2019 (COVID-19) pneumonia. Korean J Radiol. 2020;21:627-628.

8. Boussarsar M, Thierry G, Jaber S, Roudot-Thoraval F, Lemaire F, Brochard L. Relationship between ventilatory settings and barotrauma in the acute respiratory distress syndrome. Intensive Care Med. 2002; 28:406-413.

9. Kouritas VK, Papagiannopoulos K, Lazaridis G, Baka S, Mpoukovinas I, Karavasilis V, et al. Pneumomediastinum. J Thorac Dis. 2015;7:S44-S49. 